\title{
From Longan to Avocado: Economic Strategy of Farmers in Agricultural Business in Bandungan District Central Java
}

\author{
Antari Ayuning Arsi ${ }^{1, *}$ Nurul Fatimah ${ }^{2}$, Asma Luthfi ${ }^{3}$, Amin Tohari ${ }^{4}$, Retno Wulan \\ Ayu Saputri ${ }^{5}$, Yuni Paramita ${ }^{6}$
} 1,2,3,4,5,6 Department of Sociology and Anthropology, Faculty of Social Sciences, Universitas Negeri Semarang,
Indonesia

"Corresponding author. Email: antari.ayu@mail.unnes.ac.id

\begin{abstract}
Indonesia is known as an agricultural country that has a lot of potential natural resources as a capital for national development. One of the agricultural potentials currently being developed and a mainstay of agricultural production is fruit farming. Consensus and market demand which continues to increase every year causes farmers to implement strategies in order to produce fruit according to market demand. This condition occurs in almost all fruit farmers in Indonesia, including in Bandungan District, Semarang Regency, which has experienced a change in the type of commodity from longan to avocado. This strategy was carried out because many tourists who visit Bandungan prefer avocado to longan. This study aims to explain the strategy of farmers to replace agricultural production from longan to avocado and its impact on the community's economy. Researchers used qualitative methods by collecting data through observation, interviews, and documentation. Data analysis using Miles and Hiberman models, namely data collection, data reduction, data presentation, and drawing conclusions. The main urgency of this research is to look at the dynamics of fruit farming and its impact on improving farmer welfare.
\end{abstract}

Keywords: Agricultural Business, Economic Strategy, Farmers.

\section{INTRODUCTION}

Regional economic development is a process in which local governments and communities manage existing resources, create new jobs and stimulate the development of economic activity in the region [1]. Economic development aims to improve people's welfare for equity. In the concept of economic development, a more equitable distribution of income in developing countries is an important condition or condition that must be held to support economic growth [14]. The implementation of national development is usually adjusted to the regional development that is being implemented.

The abundance of natural resources makes Indonesia a beautiful and fertile agricultural country. Almost all types of plants can thrive in Indonesia. Development strategies in the agricultural sector in an area also need attention, because in addition to producing food for the population, the agricultural sector also supports industrial activities as a supplier of raw materials. This means that as a supporting sector, the agricultural sector is positioned as a supplier of food needs and industrial raw materials, controlling price stabilization and a supplier of cheap labor [13].

Economic development in the agricultural sector has been proclaimed by the government since Pelita I in 1974 through the agricultural business diversification program [4]. The main objective of this diversification of agricultural businesses is to improve the welfare of the farmers. Until now, various regions have tried to implement agricultural business diversification programs, and the most common model is combining rice plants in paddy fields and rotating crops and horticultural crops based on seasons [6].

Diversification of agricultural businesses is not the only effort made by farmers to improve their welfare. Another strategy that many farmers use to improve their welfare is by changing the types of plants planted [8][11][12]. This strategy was chosen by 
fruit farmers in Duren Village who switched their crops from longan to avocado.

Fruit farmers in Duren Village initially planted longan and avocado on their land, but because the local Bandungan longan was unable to compete with Bangkok's longan from Thailand, they then switched from planting longan to avocado. Based on this background, the authors are interested in seeing the strategies of farmers in changing the types of agricultural crops from longan to avocado, as well as knowing the impact of changing these types of plants on the economy of the community in Duren Village.

\section{METHOD}

The method used in this research is a qualitative approach with case study research. This method is chosen according to the characteristics of the object of research in describing the real situation in society. The data collection techniques used were observation, in-depth interviews, and documentation. The subjects in this study were fruit farmers in Duren Village.

This research data consists of primary and secondary data. Primary data obtained through interviews and observations. Interviews were conducted with both key informants and supporting informants. The main informants of this study were 3 fruit farmers, namely Muslimin, Nurwati, and Siswadi, while the supporting informants were 2 village officials, namely Bandoko and Purwandi. Secondary data in this study were obtained through literature in the form of journal articles and the results of previous research on strategies to improve the farmer's economy through changes in the types of plants planted. BPS data is also used as supporting data in this study.

\section{RESULT AND DISCUSSION 3.1.The Condition of Bandungan Society}

Duren Village is located in Bandungan District which is administratively included in the Semarang Regency, Central Java. Duren Village is bordered by Jimbaran and Sidomukti Villages to the north, Mount Ungaran to the west, Mlilir Village to the east, and Jetis and Bandungan Villages to the south. Duren Village has a tropical climate with an average temperature of 30 degrees Celsius. Duren Village has an area of 308,390 hectares, of which 150,293 hectares are used for rice fields and the rest for nonrice fields.

Duren Village is divided into $9 \mathrm{RW}$ or hamlets (Legowo, Jetak, Legoksari, Duren, Clapar, Kropoh, Gaton, Tengaran, and Mejing) and 43 RT. The total population of Duren Village as of July 21, 2020 was 6,160 people, consisting of 3,089 male and 3,071 female residents, so that the composition is relatively balanced in gender. RW 02 is an area with the highest population among other RWs with a population of 1023 people, while RW 08 is an RW with the lowest population, which is only 415 people. The composition of the population of Duren Village based on age is very good, where almost $70 \%$ of the population is in the productive age between 15 and 65 years, so that the dependency ratio of the population is low. Most of the residents of Duren Village work as farmers. Most of the residents of Duren Village work as farmers. The composition of the population of Duren Village based on their livelihoods is shown in table 1 below:

Table 1. Total Population in Duren Village based on Livelihoods

\begin{tabular}{|l|l|r|}
\hline \multicolumn{1}{|c|}{ NO } & \multicolumn{1}{|c|}{ PROFESSION } & TOTAL \\
\hline 1. & Farmer & 1154 \\
\hline 2. & Seller & 138 \\
\hline 3. & Entrepreneur & 962 \\
4 & Teacher & 20 \\
5. & Civic Servant (PNS) & 24 \\
\hline TOTAL & & 2298 \\
\hline
\end{tabular}

Sumber: (BPS, Desa Duren 2020)[3]

Geographically, Bandungan District is located on a plateau with cool air and has natural beauty which makes it a special attraction for tourists to visit and enjoy the natural scenery and feel the freshness of the air. The cool air and fertile soil are very suitable for planting various kinds of agricultural crops ranging from rice, vegetables, fruits, to various kinds of flowers. One of the flowers cultivated in Duren Village is the chrysanthemum flower, but this chrysanthemum cultivation is only used as additional work for the community, while the main product is fruit. Initially longan fruit was one of the leading commodities of a very well-known local product. But slowly the longan fruit is less competitive in the market.

This local Bandungan longan gets competition in the market from the Bangkok longan type from Thailand. Bangkok longan is in great demand because of its cheaper price and thicker meat. The tendency of imported longan quality to be better than local longan fruit is shifting domestic longan products. In order to maintain the continuity of this agricultural business, finally the fruit farmers in Duren Village switched to avocado fruit commodity

\subsection{The Farmers' Rasionality in the Change of Commodity Type: Longan to Avocado}

Since 2016, the people of Duren Village have started to switch to cultivating avocados and avocado tree seeds. Avocado tree seeds from Duren Village are now even marketed outside Java, from Palembang to Kalimantan.

There are several reasons why fruit farmers in Duren Village have switched from longan to avocado. 
First, compared to avocado, longan fruit care is much more difficult and requires a fairly high cost. These difficulties can be seen from the seedling period of planting to maintenance during fruiting. In one year, Bandungan longan only experiences one harvest season. Moreover, the market demand has decreased due to competition with Bangkok longan imported from Thailand. On the other hand, avocado tree care is relatively easy. Avocados can be grown in tropical and sub-tropical areas. This avocado plant is also relatively able to grow in almost all types of land and withstand various weather. The difference is the water content in the fruit. Avocado tree does not take long to bear fruit. With the cutting or grafting method, avocado trees can bear fruit faster, and can be harvested every six months.

Second, avocados are one of the commodities that have high economic value. This avocado commodity is traded both domestically and abroad. In addition to daily consumption, avocados are also used as cosmetic ingredients. This avocado business can be developed to meet market demand and can increase production results so that it can help increase the income of avocado farmers.

Third, avocado has a stable and profitable selling value for farmers. Stable prices and a market that always exists are the main attractions to make avocado a commodity. Harvesting not only once can provide many benefits and increase farmers' income. Private tree ownership by the community by planting in their yards is a promising part-time job. Even though each farmer owns no more than 3 to 5 trees, at harvest time the trees produce a very profitable product.

However, the people of Bandungan, especially Duren Village, cannot really feel the economic improvement from the change of longan to avocado plants, because avocado cultivation here is still quite young and has not been used as the main profession for the community. Moreover, the market needs the development of avocado cultivation at Desa Duren in order to produce the best quality fruit.

\subsection{The Cultivation Problems and The Farmer Strategy to Face Those}

The process of changing from longan to avocado plants is not without obstacles. Therefore, the role of community institutions is no less important behind the success of this strategy. This collective effort through community institutions is one of the strategies adopted by farmers in Indonesia and other countries in facing various obstacles including farmers in Duren Village. The role of farmer groups is related to access to funding and skills training [5][6]. In Duren Village, there are many farmer groups who have their respective commodities. One of them is the farmer group in Duren Village, the Sumber Makmur 2 Farmer Group, which implements avocado nurseries and makes fertilizers which are sold to farmers. The members of the Sumber Makmur 2 Farmer Group conducted an avocado nursery. The process, starting from getting the seeds, preparing the planting media, then sowing them in polybags and maintaining them until they are ready for sale takes approximately 4 months. Avocado plant nurseries are usually carried out during the rainy season. Sumber Makmur 2 Farmers Group only does semi-finished avocado nurseries, because many of the consumers will use these avocado seeds as cutting media for existing avocado brood trees.

The process of avocado seeding carried out by the Sumber Makmur 2 Farmer Group does not always go well. There are many obstacles that are often faced in sowing avocado seeds, such as caterpillar pests, poor quality of avocado seeds, fungal attacks, so that the seeds grow less than perfect. From these constraints, the farmer groups try to make improvements and processing in order to produce good quality seeds. Efforts to improve the quality of avocado seeds begin with increasing human resources first, starting with the participation of group members in debriefing and counseling activities held by Department of Agriculture. Every month, all members of the group also gather and have a discussion to find the best seeds for sowing.

In addition to training and mentoring for group members, farmer groups initially also provide subsidies to their members in the form of money for this avocado plant nursery. However, in the future, the development of this capital subsidy still depends on each member of the farmer group, whether it will be developed again from the initial capital or not.

During the Covid-19 pandemic, the impact was also felt by farmers who cultivated avocado plant seeds. As felt by all sectors, during this pandemic the sales turnover of these avocado seeds also decreased. One of the strategies adopted by these avocado tree seed cultivation farmers is to work with land owners who want to plant avocado trees and share their crops. With this profit sharing method, besides sharing the profits, avocado seed farmers and landowners also share the risk of failure. This strategy is considered the fairest and safest according to both farmers and land owners.

Apart from sharing the benefits and risks, fruit farmers have also returned to the old strategy of diversifying agricultural products by cultivating other commodities such as flowers, cloves and vegetables for additional income.

In addition, farmers' income has also increased since cultivating avocados. The additional yields are stored once. Then use it to buy new avocado seeds or new land. Many farmers have started cultivating avocados because they saw other farmers succeed and get good results from avocado plantations. As partners, the farmers share experiences and help each other such as giving seeds - which 
have been cut - to other farmers, planting trees together and distributing the harvest to farmers who buy seeds in the farmer groups. This is a collaboration between farmers to improve the economy of avocado cultivation in Duren Village.

\section{CONCLUSION}

Overall, even though it is not optimal, the economic strategy of the farmers from longan to avocado as a whole can be said to be quite successful. Changes in the type of commodity from longan to avocado can increase the selling price and income of farmers, thus having a positive impact on food security. In order to continue to increase and maximize this positive impact, it is necessary to have synergistic policies between the village and local governments. Improvement of farmer skills through training, improvement of agricultural facilities and infrastructure, access to capital, market expansion to export and institutional strengthening need to be continued. In addition, fertilizer or seed subsidies for farmers should be further encouraged and carried out with maximum supervision.

\section{REFERENCES}

[1] Arsyad, L. 1992. Ekonomi Pembangunan. STIE YKPN: Yogyakarta. Badan Pusat Statistik. (2016). Produksi Holtikultura 2015. BPS: Jakarta

[2] Badan Pusat Statistik. Provinsi Jawa Tengah dalam Angka 2015. BPS: Semarang.

[3] Badan Pusat Statistik. 2020. Kecamatan Bandungan dalam Angka 2020. BPS: Kabupaten Semarang

[4] Budhi, Gelar Satya. "Dilema Kebijakan dan Tantangan Pengembangan Diversifikasi Usahatani Tanaman Pangan." Jurnal Analisis Kebijakan Pertanian. Volume 8 No. 3, September 2010. Hal. 241-258.

[5] Daka, Anatole, Yijie Waang, and liang Hu. 2019. "Peasant Strategies in the Cotton Regions of Cameroon: Lessons From the Lam Cotton Zone." International Journal of Learning and Development. Vol. 9, No. 4. Hal. 38-50.

[6] Damanhuri, Rr. Merry Muspita DU, dan Dwi Putro Sarwo Setyohadi. 2017. Pengembangan Diversifikasi Usaha Tani sebagai Penguatan Ekonomi di Kabupaten Bojonegoro, Tulungagung, dan Ponorogo. Jurnal Cakrawala Vol. 11 No. 1 Juni 2017. Hal. 33 - 47.

[7] Dytanti Ilmiansi T. Siswanto,dkk. 2017. "Analisis Pendapatan Usaha Tani Alpukat pada Kelompok Tani di Kabupaten Semarang". Skripsi. Universitas Diponegoro
[8] Halimah, S. 2013. "Faktor-Faktor Penyebab Penggantian Tanaman Kemiri menjadi Tanaman Coklat di Desa Gumpang Lempuh Kecamatan Putri Betung Kabupaten Gayo Lues”. Disertasi. Unimed.

[9] Nurul Huda, Taufik Marwa,dkk. 2007. "Analisis Pertumbuhsn Ekonomi Sektor Primer di Provinsi Sumatera Selatan". Jurnal Ekonomi Pembangunan, Vol. 5. No. 1. Hal .47-58

[10] Santosa Budi Purbayu. 2005. "Pembangunan Sektor Pertanian Melalui Pola Agribisnis Menuju Ketangguhan Perekonomian Indonesia”. Jurnal Dialogue, Vol. 2. No. 1. Hal. 674-685.

[11] Sinuhaji, O. S. 2011. "Perubahan Sistem dan Pola Pertanian Rakyat Di Desa Sukatendel Kabupaten Karo Tahun 1965-2005”. Skripsi. Universitas Sumatera Utara.

[12] Sembiring, R. 2013. "Faktor yang Melatarbelakangi Petani Jeruk Mengganti Tanamannya Menjadi Tanaman Kopi di Desa Barus Julu Kecamatan Barus Jahe Kabupaten Karo". Disertasi. Unimed.

[13] Solahuddin, S. (1998). "Kebijakan Pembangunan Pertanian Pasca Orde Baru." Majalah Usahawan.

[14] Todaro, M. P. (2000). Pembangunan Ekonomi di Dunia Ketiga (edisi terjemahan) (Edisi Keen). Penerbit Erlangga. 